\title{
Oriented to English: Motivations and Attitudes of Advanced Students in the University Classroom
}

\author{
David P. Shea \\ Keio University
}

The orientation to English among university students in Japan is a complex and shifting amalgam of attitudes and experiences that shape engagement in the classroom. Although research on learner motivation has highlighted the instrumental value of EFL in terms of imagined identity and investment, motivation is also affected by social factors such as Ministry of Education, Culture, Sports, Science and Technology (MEXT) policy and teaching practice encountered prior to university entrance. In this paper, I report on a qualitative analysis of orientations among high proficiency advanced students in a 1st-year EFL class at a large university in Tokyo. Findings suggest that paths of study and admission routes varied widely, that a strong commitment to English was coupled with low levels of confidence, and that orientation seemed to shift noticeably after entering university, as students sensed the possibility of attrition and a reduced scope of English study. At the same time, students welcomed the chance to engage with content and build ideas in English as the role of the EFL classroom took on increased importance.

日本の大学生の英語への指向は一様ではなくその態度やこれまでの経験も様々であり、 英語の授業に対する意欲も日々変化している。学習者の動機づけに関する研究は、自己効 力感や自己投資に関するEFLの手段的価値を強調しているが、動機づけは同時に文部科学 省の方針や高校における入試に対する指導法のような社会的要因にも影響される。本論文 では、質的分析の方法を用い、東京の大規模なある大学の上級レベル 1 年生の英語授業に おける、学生の英語に対する姿勢を分析した。その結果、大学に入るまでの学習経験や入 学形態は様々であること、英語に対する学習意欲は高い反面自信があまりないこと、燃え 尽きの可能性や学習範囲の狭窄を感じ始め、大学入学後は英語に対する姿勢が著しく変わ ること等が分かった。しかし同時に英語で意見を構築する機会を好意的に受け入れ、EFLの 授業の役割がより重要になる傾向が示された。

JALT Journal, Vol. 39, No. 2, November 2017 
$\mathrm{T}$ he attitudes and willingness to study that Japanese students bring to the university EFL classroom are grounded in an intricate association of influences. For many incoming 1st-year students, interest in English is tied to past experiences studying the language in addition to future hopes and imagined positionings (Yashima, 2002), all of which inform attitudes and practices generated in ongoing contexts of study. Given the pronounced shift that students typically encounter between secondary school and university, Ushioda (2013) argued that "it would seem particularly relevant to explore their perceptions of what English and learning English mean" (p. 9). Although Japanese university students have a generally bad reputation for "entrenched silent behavior" and nonparticipation (King, 2013 , p. 326) as well as "far from uncommon" postures of boredom and apathy (Ryan, 2009, p. 413), there is evidence that attitudes toward English are changing throughout Japan (Seargeant, 2011), a shift that is particularly noticeable among advanced proficiency students, who often demonstrate strongly positive orientations toward foreign language study. Many of these students envision English playing a role in their future careers despite a lack of confidence and a degree of uncertainty about how English fits into the sociocultural environment at university. Looking at these orientations to language study in closer detail allows us to better understand the dynamics of the EFL classroom and the kinds of student engagement found there.

\section{Literature Review}

Research on the motivation to study English as a foreign language was for a long time conceptualized as a matter of aspiring to integrate with L2 culture, generally defined as interaction with native speakers and closer proximity to the target language community (Ushioda \& Dörnyei, 2009). However, as Pavlenko (2002) pointed out, millions of people "learn and use additional languages without giving a thought" (p. 279) to joining another cultural group, which is perhaps the case for many students in Asian contexts, including Japan. Accordingly, there has been a theoretical shift away from an integral view of motivation. Even Gardner (2007), who helped introduce the term integrative, defined motivation within a broader, more general conception of intensity, as "genuine interest in communicating" in the L2 and "favourable attitude[s] toward the language learning situation" (p. 19), rather than integration per se.

Recent research on motivation has thus tended to address language learning more in terms of the learner's own language identity, which may include the pragmatic expression of identity associated with personal goals and 
career choices. Studying English is located in "complex interplay" of "here and now" realities (Dörnyei, 2009, p. 12), as learners appropriate the idea of the foreign language to locate and enact personal goals. In Indonesia, for example, Lamb (2004) observed that learners approach English not to integrate into Western culture but to develop a globalized English-speaking "version of themselves" that is layered upon the "local L1-speaking self" (p. 3 ). Indeed, Lamb noted that the global and the local, like the integrative and the instrumental, are often intertwined and indistinguishable. English is associated with the West, but many people are "acutely aware that its social, economic and cultural effects will be felt inside Indonesia" (p. 13). In Japan, a similar trend is evident. English is fast becoming a "must have" basic skill in a globalizing society where the purpose of language study is unrelated to joining a target cultural community but is associated, rather, with personal goals and local trajectories (Ushioda, 2013).

Many discussions of learner motivation refer to Dörnyei's (2009) construct of the "ideal L2 self," postulating a "self-representation" that positions the language learner vis-à-vis English in an act of envisioning a future to live up to (Ryan \& Dörnyei, 2013, p. 91). In other words, studying English involves a kind of enactment of the imagined self, wherein aspirations shape and are shaped by the orientation to language learning. Yashima (2002) contended that students visualize themselves interacting with English in the future, adopting an "international posture" associated with "proficiency and L2 communication confidence" (p. 63). Yashima (2013) went on to suggest that the willingness to communicate, which is situated in this imagining, works to give meaning to practice and sustain learning in the English language classroom.

Ryan (2009) pointed out that the discourse about the role of English in Japan as a means of international contact and communication sends "mixed signals" to learners who are dealing with the ordinary, everyday realities of language study. This discontinuity, Ryan argued, means that the "cool and fashionable" image of English does not always translate into active study and as a result, English remains "peripheral" to many young people (p. 409). Further, Ryan contended that the commitment to English study stems in large part from the learner's personal experience in the "immediate social environment" (p. 417). He also observed that learners frequently regard the study of English at university as a kind of communicative return on the investment made in secondary school studying grammar and vocabulary (p. 409).

Ryan's (2009) conclusions highlight the layered interaction between individual orientation and influence of the surrounding environment. In some 
respects, his study echoes Norton's (2000) discussion of investment, which suggested that willingness to study the L2 is broader than a simple expression of individual intention. For Norton, motivation is always located in the construction and expression of identity situated in broader social attitudes and ideologies. In effect, motivation is shaped in part by practical considerations of access and engagement within contexts of use, determining "the multiple positions from which language learners can speak" (Norton, 2013, p. 2). Lamb (2004), too, noted that the motivation to learn English is shaped by the surrounding environment, both ideological discourses of internationalization (Kubota, 2002) and practical issues of instruction in the classroom.

One of the most significant social influences on language study in Japan is the government's official language policy as delineated in the official Course of Study and the Ministry of Education, Culture, Sports, Science and Technology's (MEXT's) increasingly strong promotion of English (Tahira, 2012). Ongoing educational reform "corresponding to globalization" seeks to foster interactional proficiency and produce Japanese who can use English on an international level (MEXT, 2014). In many secondary schools, there is growing recognition of the need to incorporate communicative approaches into the effort to teach English in English (Sato, 2015), and students' positive valuation of authentic language use by teachers reflects a "generally encouraging prospect" for communicative language teaching (Abe, 2013, p. 52). On the tertiary level, this endorsement of English is even more dramatic as more and more universities follow MEXT guidelines to implement content classes with English medium instruction (Brown, 2014; Carty \& Susser, 2015). Such curricular initiatives arguably exert top-down pressure throughout the education system.

At the same time, there is clear evidence of a gap between the rhetoric of communicative reform and the reality of L2 instruction, which is likely to have a negative effect on student motivation. Glasgow and Paller (2016) maintained that there is a "continued disconnect" between de jure policy, with its emphasis on communication, and de facto pedagogy, leaving teachers to "make sense of policy messages that are not reconciled with classroom and institutional practices" (p. 175). Communicative reform is substantially rhetorical, Glasgow and Paller asserted, which gives students little incentive to appropriate English as a practical tool of thought and action. From a slightly different perspective, Kikuchi and Browne (2009) pointed out that MEXT has in fact established communicative guidelines that have not been implemented, given the pervasive pressure on teachers to "prepar[e] students for the form-focused university [entrance] exams" (p. 176). Kikuchi 
and Browne found strong support for communicative language instruction among students, even as teachers followed one-way grammar-translation methodologies, detailed in manuals of MEXT-approved textbooks. Sakui (2004) recorded similar disjuncture among teachers trying to introduce communicative language practices in the face of having to prepare for "grammar-skewed" exams (p. 159).

The widespread perception, held by many observers, is that EFL education in Japan is a "failing system" in crisis (Ryan, 2009, p. 407), a result of the ineffective "orthodoxy" of traditional grammar-translation instruction in secondary schools (Aspinall, 2012, p. 87). Test-driven, noncommunicative teaching is seen to engender significant demotivation among students (Kikuchi, 2009, 2013). There is also a prevalent feeling that tertiary EFL study is characterized by "apathy, passivity or lack of learning purpose and engagement" (Ushioda, 2013, p. 9). And yet, when Falout (2012) admitted that the foreign language education system may be test driven and impractical, he also observed that internal factors mediate external influence, remarking that what matters more is "not what learners experience as much as how they perceive and react to their experiences" (p. 6). With this caveat in mind, it is important to catalog student voices and to ask how learners actually perceive English and orient themselves to language study. In the following sections, I report on an action research project involving high proficiency 1st-year university students. Although learners with advanced fluency in English are certainly not representative of the larger university student population in Japan, they nonetheless offer valuable evidence of attitudes and experiences that affect instruction and shape the way we think about EFL pedagogy.

\section{Methods: Aims and Procedures}

To better understand student orientations to English, I carried out an exploratory study of 1st-year university classes that I teach, following principles of reflective practice (Walsh, 2011) and action research (Burns, 2010). I collected data related to "issues of practical and personal concern" in the classroom (Burns, 2000, p. 4-5), with the goal to "enhance understanding of the local context rather than generalize to a broader one" (Walsh, 2011, p. 142). To this end, I surveyed student opinions with a series of questionnaires and follow-up interviews, asking about English in general and EFL study in particular. Although the proximity to students in my own classes allowed a deeper understanding of the context in which students responded, there was also potential for bias, so I took particular care not to conflate research 
with teaching. All surveys were anonymous with no means to connect a response with a respondent. Oral and written permission was collected from students at the beginning of the year, and principles of informed consent were followed. I promised that privacy would be protected, all names kept anonymous, and comments polished for grammar (to minimize embarrassment). Both interviews and data analysis were carried out after final grades had been submitted to avoid a conflict of interest.

Data were collected over three semesters, spring and fall in 2013 and spring in 2014, from a convenience sample primarily comprising students enrolled in a required 1st-year content-based English communication course I have taught for a number of years at a large private university in the Tokyo metropolitan area. The course was divided into two distinct classes: regular (hereinafter ippan) and returnee, both designated advanced. Most students had strong oral proficiencies, although there was noticeable variation within the two classes. Enrollment in the ippan class was determined by scores (between 450-495) on the listening section of the TOEIC IP test, which was used as a placement measure. Students were assigned to the returnee class according to the university admissions classification, defined as having lived abroad in an English-speaking environment for more than 2 years. Approximately two thirds of the returnee students had attended the university's attached high school in the United States before returning to Japan and were automatically assigned to the advanced class even though a few (three or four students) had intermediate proficiency and would likely not have been placed into the advanced class had they taken the TOEIC. The returnee classes included six or seven students who had studied abroad but did not attend the attached high school. Also of note was that because of scheduling issues, three or four students from the ippan class attended the returnee class, and two or three returnees sat with the ippan class. Each class had 20-25 students enrolled, although respondent numbers differ due to attendance on days when the surveys were conducted.

I carried out a variation of four surveys in 12 classes over the three semesters. The surveys were administered to both ippan and returnee classes at the end of the spring semester 2013, followed by a set of surveys during the fall semester 2013 and at the end of the spring semester 2014. For heuristic purposes, I considered responses from the ippan and returnee classes in both years within the same category. That is, when I refer to the ippan class, I am including data from both 2013 and 2014 classes. I have also included a set of open-ended responses to one survey given to students in an elective academic writing seminar, which I also taught during the same time period. 
All surveys were written in English and consisted of a combination of forcedchoice Likert-scale statements (indicating agreement or disagreement) and open-ended questions to which students could respond in either English or Japanese. There were over 400 open-ended comments in total. The surveys and the classes in which they were administered are summarized in Table 1. Abbreviated versions of the four major surveys are included in the appendix to give a general idea of the questions asked. In citing student comments throughout the paper, I refer to survey codes with attached numbers that reference a location within the data set.

Table 1. Surveys

\begin{tabular}{lllll}
\hline Code & Class & $N$ & Date & Topics \\
\hline SSI & Ippan Film & 24 & Spring 2013 & attitudes toward English \\
SSR & Returnee class & 20 & Spring 2013 & attitudes toward English \\
CSI & Ippan Film & 25 & Spring 2013 & open-ended Qs re English \\
CSR & Returnee Film & 20 & Spring 2013 & open-ended Qs re English \\
SOI & Ippan Film & 25 & Fall 2013 & English use, HS activities \\
SOR & Returnee Film & 20 & Fall 2013 & English use, HS activities \\
SOW & Writing seminar & 13 & Fall 2013 & English use, HS activities \\
SR & Returnee Film & 18 & Fall 2013 & attitudes toward English \\
CSI & Ippan Film & 25 & Fall 2013 & open-ended Qs re English \\
CSR & Returnee Film & 20 & Fall 2013 & open-ended Qs re English \\
SRI & Ippan Film & 17 & Spring 2014 & HS activities, attitudes to \\
& & & & English \\
SRR & Returnee Film & 20 & Spring 2014 & HS activities, attitudes to \\
& & & & English \\
\hline
\end{tabular}

To follow up particular questions and lines of thought that emerged in the analysis, I arranged a set of three interviews with seven students from the 2013 ippan class, selected on the basis of active participation and willingness to volunteer. I audio recorded and transcribed the conversations, which followed a semistructured format and lasted approximately 30 to 45 minutes, and I asked a range of questions about attitudes toward language study. The interviews, which took place in English, were carried out after 
grades had been turned in-and I paid for the coffee. Moreover, I asked two students from the returnee class to answer additional follow-up questions via email. Interview details are summarized in Table 2.

\section{Table 2. Interviews}

\begin{tabular}{lll}
\hline Code & Participants & Date \\
\hline IMS & Michiko \& Sachiko & Jan 30, 2014 \\
IASR & Arisa, Sayako, Rosa & Jan 31, 2014 \\
IMR & Mai \& Ririko & Feb 4, 2014 \\
ITM & Teri \& Mami & Email \\
\hline
\end{tabular}

\section{Data Analysis}

To carry out the analysis, I followed procedures of qualitative inquiry (Patton, 2015; Thomas, 2006). For the Likert questions, I calculated simple totals and percentages as a general indication of response, not to establish statistical significance, especially because respondent numbers varied from survey to survey. Although percentages of small sample sizes are in no way statistically valid, a number does indicate a broad tendency of response. I approached both survey and interview data with the same analytic lens, seeking to generate interpretive categories based on an inductive approach. In a sense, I was trying to generate a cohesive narrative (Pavlenko \& Lantolf, 2000) of opinion in a way that made sense of student perspectives. To analyze open-ended comments, I first generated a list of preliminary categories while looking to identify general patterns, commonalities, and salient themes. Following iterative readings of the data set, I refined categories, combining and delineating relationships, aiming to draw conclusions about the research questions. I narrowed the analysis until axial categories emerged, allowing a "grounded" interpretation of student orientation, which I present below.

\section{Findings}

\section{Diversity of Background}

The most well-defined albeit unexpected finding that emerged from the analysis was the striking diversity of contact with English prior to university. Students studied at different kinds of schools where they experienced an array of instructional approaches in a variety of distinct settings. In addition 
to returnees, a surprising number of ippan students, almost half the class, reported having lived abroad or attended school in an English-speaking environment for varying lengths of time and for different purposes. What is more, students gained admission to the university through multiple gates, ranging from the entrance exam to high school nomination, attached high school automatic acceptance, foreign exchange, and returnee designation. High schools themselves differed broadly, with diverse curricula and contrasting instructional activities.

Further, students diverged noticeably in their estimation of the effectiveness of the study they had experienced in high school. Indeed, the majority of ippan students reported receiving some form of "traditional" instruction, with emphasis on intensive reading, close translation, and explanation in Japanese about grammar and vocabulary. Among the 2014 ippan class, for example, $76 \%$ of the students reported that their high school English instruction was "mostly grammar-translation" (SRI). When asked about the biggest difference between English study in high school and university, many students mentioned this focus on traditional instruction:

In high school . . . we studied English by using Japanese. (SOW-3)

We mostly read and translated. I don't remember speaking English in high school. (SRI-2)

Never spoke my ideas in English ... Never had a conversation. (SRI-6)

Teachers talked and we just took notes. (IMS2)

At the same time, many students also reported having been engaged in a variety of communicative activities not typically associated with traditional instruction, ranging from reading extensively to academic writing, oral presentation, discussion, and even debate. In the returnee section, this trend stood out, with less than a third of students reporting a focus on grammartranslation in high school:

I took three different kinds of classes: English, creative writing, and reading. When I came to the university, I was ready to join in since I had read novels and learned to write an essay. (SRR-13u)

Mostly we read English books and discussed them in class. (SRR-6u) 
My high school English classes involved a lot of academic writing, oral practice, and reading. (SRR-6e)

However, the diversity of instructional approaches to high school English study was also evident in the ippan class, where a high percentage of students reported taking classes with communicative instruction, involving such activities as academic writing and reading extensively. For example, approximately half of the ippan students reported reading a novel in high school English classes (SSI), and a clear majority (71\%) reported doing reading that involved novels and stories (SRI). Most (81\%) reported watching a movie in English as a class assignment, and a small but not insignificant number $(15 \%)$ reported having written journals in English, although a much larger number $(71 \%)$ stated that they did some other form of academic writing (SRI). Nearly a quarter of ippan students responded that they "got a lot of practice in oral English" (SRI). Open-ended comments support the impression of curricular diversity. Ippan students wrote, for example,

I've written many essays in MLA style, which helped me understand citation. (SOI-4)

Debate ... gave me a chance to read information in English and speak persuasively. (SOI-5)

I read many novels, such as Killing the Mockingbird [sic], Animal Farm, and news articles. I also wrote many essays for homework. (SRI-10)

In some cases, the focus on communicative instruction seemed to replace a grammar-translation approach; in other cases, interactive, meaning-focused activities appeared to have been implemented in a supplementary manner. Although some students did not seem to find the activities exciting, their remarks highlight the fact that there was, in essence, a good deal of instruction that was "communicative" in nature. For example, one student wrote:

In high school, there were few writing activities and it was just reading novels each quarter and quizzes. (SOR-4)

Although the student is somewhat dismissive of the activity, it is clear that there was a substantial amount of reading for meaning, which certainly qualifies as communicative study.

On the whole, traditional instruction based on grammar-translation was largely received with skepticism by students, with many critical of the ap- 
proach. One student wrote that high school English did not improve proficiency:

The communication class was too easy for me and I was always translating for everyone. (SOI-1)

Much of the criticism was that ideas were lost in the focus on grammar, with little opportunity to improve speaking skills or discuss larger ideas:

We didn't discuss. We were not allowed to discuss in high school. (SOI-24)

At the same time, a number of students reported that they felt grammartranslation instruction was, in point of fact, effective. One student mentioned that word tests were particularly helpful for acquiring vocabulary, raising awareness, and learning to look up meaning, and others stated that they felt grammar to be an effective tool to improve both spoken and written proficiency:

If you're good at grammar, you can speak proper English. (SRI-14)

Grammar practice helped a ... bit when writing an essay in high school. (SRR-1e)

Grammar was the most helpful in high school because I need good grammar to write an essay. (SOW-10)

Interestingly, most students seemed to have actually liked their English lessons in high school. Nearly two thirds of the ippan class indicated that they felt largely positive about English class (SSI). A similar majority (68\%) reported that they felt their high school classes were "generally effective to learn English" (SOI). In other words, although some students said they found traditional grammar study boring, others said they found it effective and stimulating.

A final point relates to the context of learning. In the returnee class, all students had lived abroad in an English-speaking environment or had attended an English medium school for at least 2 years. An unexpected finding was that many students in the ippan section, more than half, also reported having spent significant time abroad, more than a year, either as a young child or as an older exchange student. For some, the experience outside Japan brought an advanced language proficiency or laid a foundation that 
later proved effective. Here again, however, what is striking is the diversity of experience. A third of ippan students reported never having lived abroad. Yet within this subset, many had particular access to English in some form, whether a family connection or a personal hobby that involved supplementary use of English outside the classroom. For example, two students wrote,

My education in high school did help me improve my grammar to some extent, but the reason I am in [the advanced] class is because of my mother's intense English education when I was 0-6 years old. (SRI-3)

In high school, I never had a chance to speak ... English [which] was definitely not enough, so I watched American movies and dramas on my own. (SOW-11)

In both cases, students are talking about extra preparation outside the regular school context. In the first, preparatory instruction was provided by the student's parent. In the second, additional study related to a personal interest that is often reported as providing a gateway into English: TV and movies. The comments point to the probability that many, perhaps most of, the students in the advanced classes seem to have had access to some kind of study outside the regular high school curriculum. Although I did not look at supplementary instruction in this study, cram schools and preparatory academies are likely a big part of the language-learning landscape. What can be said with some certainty, though, is that the kind and extent of preparation is noticeably diverse, and students have travelled divergent paths and engaged in distinctly different styles of preparatory study before entering the advanced class at a respected university. The question then arises: How do they orient to English once enrolled?

\section{High Aspiration, Low Confidence}

The second finding to emerge from the analysis involved juxtaposition between aspiration and assurance. On the one hand, most students expressed strongly positive attitudes toward English, both as a subject of study and as a means of personal definition. On the other hand, most students also reported hesitation and low self-confidence regarding their ability. Some defined themselves as English speakers but most did not, and for both groups, ippan and returnee, this orientation was relative, depending on the context. That is, students expressed a strong sense of investment in English, reflecting an awareness of its cultural value and status, even as they found it difficult to imagine actually using their investment effectively. 
In both groups, all but a few students agreed that they "liked" English, a markedly higher percentage than those who said they liked their high school English classes (92\% vs. 62\%). Clearly, English carries high prestige and symbolic value among students, as it is associated with widely reported opportunities for employment, travel, and entertainment. Even the four students who said they did not like to study English nevertheless agreed that the language represented a useful tool. All but two students stated that they thought English would be helpful in the future (SSI, SSR). From the students' point of view, there is definitely a felt need to study the language, certainly in the present and probably in the future. Every student, including those who said they did not like English, declared a strong intention to study hard at university to improve their language skills. Even those who expressed dislike appeared committed to language study.

In contrast, the number of students who expressed confidence in their own language proficiency was perceptibly low. Only a quarter of the ippan class and less than half (40\%) of the returnee class expressed confidence in their English skills (SSI, SSR). Along similar lines, many students stated that they were reluctant to define themselves as proficient. In spite of having placed into the advanced class, less than half (40\%) of the ippan students agreed that they consider themselves English speakers (SOI), though the figure was higher (70\%) for returnees (SOR). Further, a number of students, nearly a third of the ippan and almost half of the returnees, indicated that they lack pride in their English proficiency (SOI, SOR). In fact, a third of the returnees agreed that they would not want to be seen by Japanese classmates as an English speaker. In sum, commitment levels were strong while confidence levels were weak.

The low estimation of ability is certainly not a realistic appraisal given the demonstrably strong abilities evident in class performance and test scores. The lack of confidence undeniably reflects culturally situated attitudes of modesty. In downplaying their own abilities, students were likely trying to avoid what might appear to be self-congratulatory claims of competence. Additionally, part of the ambiguity in talking about confidence is that students envision different contexts of use when they respond, but successful practice generally brings greater assurance. For example, students who expressed confidence in English grounded their reasoning in classroom activity. Two ippan students stated,

I went to international school in China from 5th to 8th grade and ... I had to take all classes in English. (SRI-2) 
I learned how to write an academic essay and to pick up important and key details from a story. (SRI-1)

For both, confidence grew from concrete use. Along similar lines, 40\% of returnee students in the spring semester reported having confidence in their English skills (SSR), but the number rose noticeably the following term, with $72 \%$ agreeing that they had confidence speaking English in class (SOR). By the second survey, the students had had 3 months of weekly class sessions in which to engage in discussion activities, expressing ideas and participating in productive, supported oral practice.

A number of students described the lack of confidence in terms of interaction with native speakers outside school contexts. For example, Mami, one of the returnees, said:

I get nervous when there is another fluent speaker because I think about if my grammar is wrong or if I'm saying things right... The only time I actually speak to real native speakers . ... the nervousness is huge and I stumble on. (ITM-2)

One of the ippan students, Michiko, explained that she didn't think of herself as an English speaker:

... because I don't have an opportunity to use English in my daily life. (IMS-2)

Both students were voicing a conception of English as a means to communicate with native speakers from abroad. In this respect, English is the language of the Other, not Japanese. Defining oneself as an English speaker intrudes on this dichotomy and challenges the privilege of the native speaker.

The lack of confidence may also be connected to the broader social context of high school study, in which contact with English is almost universally oriented toward university admission and, in most but not all cases, entrance exams. As one student remarked, "Teachers taught us how to get a good score on exams to enter the university." In other words, the goal of high school English study was strongly instrumental: to do well on the test. The effect of this orientation was to frame English as preparatory with a focus on getting the right answer that has consequence for a future orientation to the language.

Another returnee, Sayako, noted this contextual frame even in the progressive secondary school she attended where there was a great deal of 
communicative instruction. She said that in high school, she "didn't like speaking" because her "opinions were either right or wrong" (IASR-2), and she always felt "the pressure" to be right. Interestingly, Sayako explained her comments about correctness in terms of the change in orientation she felt at university, where, she said,

Everything is right, you just say what you want to say, so [there's no] pressure that the answer might be wrong. (IASR-2)

The point Sayako was making is that the aim of discussion in the university class was not to produce the right answer, but to generate an insightful response that made sense and expressed an interesting, persuasive idea, which is an issue of personal expression-what she thought and wanted to say, rather than correctness.

In short, it seems that many students lacked confidence in part because they were always being evaluated as right or wrong. With a focus on correctness, students faced the likelihood of error, especially considering the difficulty of many entrance exams. Within the preparatory framework in which English is studied in high school, the pressure to give the right answer seems to make it difficult to express ideas or speak with confidence because the stakes are so high.

\section{Both Toward and Away}

The third finding to emerge from the analysis was that the orientation to English seemed to change significantly upon entering university. Students appeared to develop a more integrative relationship with the language that entailed both subtractive and additive dimensions. On the one hand, many students, particularly those who had lived abroad (both returnee and ippan), reported feeling a sense of language attrition due to their reduced contact with English. On the other hand, students began to see English less as a subject of study and more as a tool of critical thinking and expression, which was connected to the shift toward content-based instruction in university EFL classes. This tension in orientation, both toward and away from English, points to the mediating role of the classroom.

Students seemed to feel that, compared to high school, English at university has a reduced presence because for most students the number of classes per week dropped, reducing the quantitative sense of connection, and other activities intruded upon time for language study. The biggest difference between high school and university, one student said, was 
... using English every single day [in high school]. In university, it is hard to focus on studying English since there are many other things to study in Japanese. (SOR-16)

The student was referring, first, to the reduction in the number of overall class hours. Whereas English was a major component of the high school curriculum, the connection is less intense at university, where two classes per week is the norm for students in this study. (It is possible to take more, although not required.) The student's comment also noted social pressures working against English. Whereas in high school there is a broad energy generated by preparation for university exams and admission, the tension dissipates at university as other commitments increase. In this respect the sphere of English narrows after high school.

More than two thirds of students in both ippan and returnee classes reported that they felt it difficult to use English outside the university classroom, which is perhaps why only a minority, slightly more than a third, reported that they use English in some way almost every day (SOI, SOR). With a few noticeable exceptions, supplementary activities to maintain contact with English were also limited. Two students reported joining English club activities such as the international relations circle, and a handful of students listed a range of extracurricular pursuits that involve English: surfing the Internet, reading newspapers, viewing TED talks, and so on. Watching English films was especially popular (SSI), but the scope and effectiveness of individual study appeared limited. All but two returnees reported feeling that their English ability was declining the longer they lived in Japan (SR), and ippan students with experience living abroad asserted that they, too, felt attrition. Mai, for example, complained that, after returning to Japan, she had "forgotten a lot of English" (IMR-1), and Arisa stated that her pronunciation and fluency were "going down" (IASR-1).

Reinforcing this tendency was the difficulty students found using English with other Japanese. Commenting on another student's claim that "it's easy to use Japanese with friends" [not English] (SR-2), Ririko and Mai concurred, stating that they ordinarily reserve English either for the classroom or for interaction with non-Japanese:

(R) You only use English in English class, so (M) we don't have much time or opportunity because we can speak in Japanese. If there are no native speakers around, there's no need to use English. (IMR-1) 
In her interview, Rosa echoed the opinion, commenting that she felt her lack of proficiency and confidence precluded using English with fellow Japanese:

It's hard to use English to each other, [it's] impossible, because my English is not good enough. I don't have confidence to speak to other students (IASR-2)

A number of other students also reported that the chance to use English communicatively was limited to the English classroom:

This class is my only chance to use English in my university life, so I was motivated every week. (CSFR-1)

I didn't have other opportunities to speak English, so class helped maintain my speaking skills a lot. (CSFI-15)

In terms of the quality of contact, however, English at university created a broader, stronger focus in the classroom, where there was significant expansion in the scope of study. Students reported a move away from the preparatory test orientation of high school, accompanied by a shift toward academic subject matter involving interpretation, argument, and discussion in content-based instruction. Students indicated a strong endorsement of this change. Over $80 \%$ agreed that they would prefer to study a subject in English rather than study English itself (SOI, SOR). Students described this difference in focus as expressing ideas, with concern for persuasiveness or clarity, not correctness:

We studied mainly grammar in high school, but [at university] we've studied telling our own ideas and learning the ideas of other students. (SOI-12)

In high school, I didn't get to express my own ideas. (SOI-5)

I found that there were no answers about many problems. Even if I have a different idea from others, I don't have to feel bad. (SOI-7)

Addressing problems and engaging with classmates in English was received positively. Talking about ideas provided the opportunity, as one student said,

to think deeply, which I don't have many chances to do in my daily life. (CSFI-1) 
Rosa pointed out the fundamental value of productive expression within the future trajectory she envisioned for her career:

Most classes at university are with many people, large lectures, so English is the only place where I can express my idea. When we grow up and go out into the world, we can prepare. I want to work in the field of international relations, so I do think about this need to express ideas. (IASR-2)

Rosa's comment points to the value of developing productive ability in her L2. Her remarks also illustrate how the quality of English study increased while the overall quantity of class time decreased. Left to their own resources, a minority of students thrived with the increased independence of university, but most seemed to struggle, losing some of the proficiency they thought they had gained in high school. Without the pressurized stimulation of exam orientation in high school, not a few students felt more dependent on the university EFL classroom as the primary source to develop their English proficiency.

Within this contrasting tension surrounding English, students expressed a strong positive orientation toward interaction with classmates, from whom they drew inspiration and encouragement:

I didn't need to hesitate in speaking. Everyone does much better than me, so I'm encouraged to speak more. (CSFI-10)

Other people speak English fluently and have insightful ideas; I learned many things from other people. (CSFI-17)

Some people are very enthusiastic and they influence me in a good way. (SR-24)

Ironically perhaps, the social pressure that works against using English outside the classroom with peers seems to work inside the classroom to encourage collaboration and shared discussion. Outside the school context, English is defined in terms of the Other, but inside, a different relationship is constructed, with a more proximal orientation and a stronger sense of personal investment associated with discussing ideas and interpretations with fellow classmates.

\section{Discussion and Implications}

In this paper, I have tried to delineate key orientations to English and English study that advanced 1st-year students report bringing to the university 
EFL classroom. First, there is a striking diversity of backgrounds and kinds of language study in which students were engaged. Although intensive and preparatory, study prior to university entrance appears to be generally effective, at least from one point of view, in that a great deal of energy and commitment to language study is evident among students who have developed advanced proficiencies. Second, students demonstrated a strong recognition of the instrumental value of English, but this valuation was not matched by confidence or self-assurance. Clearly, there are cultural injunctions against boasting, but the concern for correctness seemed to undermine the investment in English even though confidence in language skills appeared to increase with sustained opportunities for use. Third, there was a repositioning of identification with English after entering university with less time given to language study overall but more focus given to content, a shift that was received positively, especially when the class atmosphere was supportive and worked to facilitate participation, eliciting, as one student phrased it, chances to "think deeply."

Student comments shed critical light on some of the dynamics of language study in the Japanese university. They suggest, for example, that the commitment to study English does not invariably "dissipate" once the pressure of entrance exams has passed (Aubrey, 2014, p. 156). Nor does the "disjuncture" of instructional style between high school and university necessarily produce confusion or prove a barrier to learning (Gold, 2015). In fact, students seemed to welcome the opportunity to move from studying English to studying subject matter in English, though many did seem to have trouble balancing the various social and academic commitments surrounding language study. From my perspective, actively constructing and expressing ideas sometimes proves difficult for learners, but student comments suggest that most welcome the chance to engage with content, building ideas expressively and collaboratively with the support of classmates.

Admittedly, the advanced, high-proficiency students in this study are not representative of other students in Japan. Most are academically talented and score well above average on critical test measures. Further, many, but not all, come from families with the financial resources to live abroad, supplement regular tuition with after-school instruction, or both, and there is evidence that a widening economic gap works to divide students who embrace English and those who reject it (Block, 2015). Economic circumstances, however, do not invalidate the hard work and commitment that the advanced students bring to English study. In this respect, the students in this study reflect both the vitality and flexibility of EFL education in Japan, 
and the struggle to develop new identifications with the language. Advanced students suggest that it is possible to make English a part of identity, not by following the same trajectory as that defined in secondary school contexts, but by appropriating a similar energy and engagement with L2 study.

It seems important to note that advanced proficiency students do not justify traditional approaches to EFL instruction, still prevalent in many secondary schools, simply because they have succeeded academically. In fact, I would argue that findings from this study suggest the opposite: that EFL education in Japan is changing rapidly and that traditional grammartranslation instruction in secondary schools is steadily giving way to more active, communicative use of English. Many critics of language education argue that not enough is being done to change teaching practices and implement "communicative" language teaching. Without doubt, there is room for improvement, but there is also risk of missing the diversity and vigor that advanced students represent. Student comments in this study indicate that recent innovations in high school programs, such as bilingual immersion initiatives and "international" Super English Language High School programs (Noguchi, 2015), are having a positive effect on performance and motivation. There are also many individual high school teachers who, in spite of pressures associated with university entrance exams, have nevertheless developed creative, innovative pedagogies in EFL classrooms (Sato \& Hirano, 2014). As globalizing forces continue to push Japanese society to incorporate English, pragmatic responses of students actively appropriating English are likely to grow even stronger.

In many discussions of EFL pedagogy a sharp distinction is drawn between communicative language teaching (CLT) and grammar-based exam preparation, but findings from this study suggest that this contrast may be somewhat overstated. If the word communicative is defined as the exchange of meaning, CLT would include both reading, which is at the heart of the exams, and teacher-fronted lectures. A CLT approach is not always interesting, nor is exam work necessarily dull. Pedagogically, the question is not what particular teaching method is employed (Kumaravadivelu, 2003), but whether the lesson is interesting, accessible, and relevant. At the same time, it seems valid to ask whether students are positioned as active producers of ideas or passive recipients of knowledge, an arrangement that seems especially common while preparing for exams-although here, too, the issue is not one or the other but a balance between the two. To be fair, students are not always positioned receptively in secondary English classes because more and more high school students seem to be getting the chance 
to construct ideas and express opinions both orally and in writing. In fact, there may be growing recognition that constructing knowledge via engaged productive output (Swain, 2000) is perhaps the most effective preparation for entrance exams, which are, increasingly, more about interpretation and less about grammar.

Gardner (2007) pointed out that "what is meant by 'learning' the language" has "different meanings at different stages of the learning process" (p. 13). In advanced stages of acquisition, characterized by what Gardner called "automaticity and thought," the student "no longer thinks about the language, but thinks in the language" (p. 13). This development perhaps could also describe what is happening for many students in the transition to university where language is becoming a tool of study. At the same time, the findings point to strong monolingual pressures restricting the scope of English as a "foreign" language outside the classroom-and possibly inside as well. In this respect, the EFL classroom takes on increased importance because it allows students to get past the unstated ideological assumption that English is to be used with cultural Others. When English is spoken among Japanese classmates to develop ideas and interpretations in collaborative discourse, a fundamental connection is made between social activity and thinking (Mercer \& Howe, 2012). Engaging in shared interaction generates not only confidence, but also new cognitive patterns and cultural expectations about language use. English becomes the medium of student-tostudent interaction-if, of course, the interaction is in English. Recent SLA research has been strong in its endorsement of using L1 in the classroom, but the effectiveness does not necessarily apply to contexts where there is a need to protect the only English-speaking environment to which many university students have access. Support for the L1 can be demonstrated by the teacher in other ways than letting students work on their own in the L1, which is difficult to prevent in small group contexts.

Thompson (2008) contended that much discussion of classroom pedagogy within the dialogic framework of sociocultural theory has emphasized internalization but missed the value of externalization and the fundamental ties between learning and the expression of ideas. Similar to Swain's (2000) endorsement of productive output, Thompson's point about extended talk and "opportunities for sustained thinking" (p. 243) is a reminder that, like motivation, the atmosphere of inquiry is not given but generated. This makes it even more important to consider investigation of student views, as knowledge is negotiated and new ideas as well as new identities are constructed in the dynamic space of the foreign language classroom. 


\section{Acknowledgments}

I am grateful to the four anonymous reviewers who made a number of critical comments on earlier drafts of this paper. Without their feedback, the paper would never have seen the light of day. Special thanks also go to Bernie Susser for his encouragement and scholarly comments. I am grateful to the Faculty of Business \& Commerce for granting a sabbatical, which allowed time to write, and I particularly want to thank the students in my classes who agreed to participate in this research project and allowed me to use their feedback and opinions.

David Shea has taught a wide variety of academic English classes on the university level in Japan since 1993. He has published articles on pedagogy, intercultural pragmatics, and bilingualism. He is currently Associate Professor in the Faculty of Business \& Commerce at Keio University.

\section{References}

Abe, E. (2013). Communicative language teaching in Japan: Current practices and future prospects. English Today, 29(2), 46-53. https://doi.org/10.1017/S0266078413000163

Aspinall, R. W. (2012). International education policy in Japan in an age of globalisation and risk. Leiden, the Netherlands: Brill.

Aubrey, S. (2014). Development of the L2 motivational self system: English at a university in Japan. JALT Journal, 36, 153-174. Retrieved from http://jaltpublications.org/jj/archive

Block, D. (2015). Social class in applied linguistics. Annual Review of Applied Linguistics, 35, 1-19. https://doi.org/10.1017/s0267190514000221

Brown, H. (2014). Contextual factors driving the growth of undergraduate Englishmedium instruction programmes at universities in Japan. The Asian Journal of Applied Linguistics, 1, 50-63.

Burns, A. (2000). Action research and applied research: What are the relationships? The Language Teacher, 24(7), 3-5. Retrieved from http://jalt-publications.org/ $\mathrm{jj} /$ archive

Burns, A. (2010). Doing action research in English language teaching: A guide for practioners. London, England: Routledge.

Carty, P., \& Susser, B. (2015). Global education and classroom teaching: From CBI to EMI. In P. Clements, A. Krause, \& H. Brown (Eds.), JALT2014 Conference Proceedings (pp. 1-8). Tokyo: JALT. Retrieved from http://jalt-publications.org/ $\mathrm{jj} /$ archive 
Dörnyei, Z. (2009). The L2 motivational self system. In Z. Dörnyei \& E. Ushioda (Eds.), Motivation, language identity and the L2 self (pp. 1-8). Bristol, England: Multilingual Matters.

Falout, J. (2012). Coping with demotivation: EFL learners' remotivation processes. TESL-EJ, 16(3), 1-29.

Gardner, R. C. (2007). Motivation and second language acquisition. Porta Linguarum, 8, 9-20.

Glasgow, G. P., \& Paller, D. L. (2016). English language education policy in Japan: At a crossroads. In R. Kirkpatrick (Ed.), English language education policy in Asia (pp. 153-180). New York, NY: Springer International.

Gold, J. D. (2015). University EFL misaligned expectations: Overcoming learning disjuncture. In P. Clements, A. Krause, \& H. Brown (Eds.), JALT2014 Conference Proceedings (pp. 9-19). Tokyo: JALT. Retrieved from http://jalt-publications. org/proceedings

Kikuchi, K. (2009). Listening to our learners' voices: What demotivates Japanese high school students? Language Teaching Research, 13, 453-471. https://doi.org/10.1177/1362168809341520

Kikuchi, K. (2013). Demotivators in the Japanese EFL context. In M. T. Apple, D. DaSilva, \& T. Fellner (Eds.), Language learning motivation in Japan (pp. 206224). Bristol, England: Multilingual Matters.

Kikuchi, K., \& Browne, C. (2009). English educational policy for high schools in Japan: Ideals vs. reality. RELC Journal, 40, 172-191. https://doi.org/10.1177/0033688209105865

King, J. (2013). Silence in the second language classrooms of Japanese universities. Applied Linguistics, 34, 325-343. https://doi.org/10.1093/applin/ams043.

Kubota, R. (2002). The impact of globalization on language teaching in Japan. In D. Block \& D. Cameron (Eds.), Globalization and language teaching (pp. 13-28). London, England: Routledge.

Kumaravadivelu, B. (2003) Beyond methods: Macrostrategies for language teaching. New Haven, CT: Yale University Press.

Lamb, M. (2004). Integrative motivation in a globalizing world. System, 32, 3-19. https://doi.org/doi:10.1016/j.system.2003.04.002

Mercer, N., \& Howe, C. (2012). Explaining the dialogic processes of teaching and learning: The value and potential of sociocultural theory. Learning, Culture and Social Interaction, 1, 12-21. https://doi.org/10.1016/j.lcsi.2012.03.001

MEXT. (2014). English education reform plan corresponding to globalization. Retrieved from http://www.mext.go.jp/en/news/topics/detail/1372656.htm 
Noguchi, J. (2015). Secondary English education in Japan. In B. Spolsky \& K. Sung (Eds.), Secondary school English education in Asia: From policy to practice (pp. 33-46). London, England: Routledge.

Norton, B. (2000) Identity and language learning: Gender, ethnicity and educational change. Harlow, England: Longman.

Norton, B. (2013). Identity and language learning: Extending the conversation (2nd ed.). Bristol, England: Multilingual Matters.

Patton, M. (2015). Qualitative research \& evaluation methods (4th ed.). Los Angeles, CA: Sage.

Pavlenko, A. (2002). Poststructuralist approaches to the study of social factors in second language learning and use. In V. Cook (Ed.), Portraits of the L2 user (pp. 275-302). Bristol, England: Multilingual Matters.

Pavlenko, A., \& Lantolf, J. P. (2000). Second language learning as participation and the (re)construction of selves. In J. P. Lantolf (Ed.), Sociocultural theory and second language learning (pp. 155-177). Oxford, England: Oxford University Press.

Ryan, S. (2009). Ambivalence and commitment, liberation and challenge: Investigating the attitudes of young Japanese people towards the learning of English. Journal of Multilingual and Multicultural Development, 30, 405-420. https://doi.org/10.1080/01434630902928447

Ryan, S., \& Dörnyei, Z. (2013). The long-term evolution of language motivation and the L2 self. In A. Brendt (Ed.), Fremdsprachen in der Perspektive lebenslangen Lernens [Foreign languages in the perspective of lifelong learning] (pp. 89-100). https://doi.org/10.3726/978-3-653-03571-1/8

Sato, K., \& Hirano, M. (2014). School-wide collaborative action research for curriculum development. In N. Sonoda \& A. Krause (Eds.), JALT2013 Conference Proceedings (pp. 130-141). Tokyo: JALT. Retrieved from http://jalt-publications.org/proceedings

Sato, R. (2015). The case against the case against holding English classes in English. The Language Teacher, 39(5), 15-18. Retrieved from http://jalt-publications. org/tlt/archive

Sakui, K. (2004). Wearing two pairs of shoes: Language teaching in Japan. ELT Journal, 58, 155-163. https://doi.org/10.1093/elt/58.2.155

Seargeant, P. (2011). Introduction: English in Japan in the era of globalization. In P. Seargeant (Ed.), English in Japan in the era of globalization (pp. 1-12). Houndmills, Hampshire, England: Palgrave Macmillan.

Swain, M. (2000). The output hypothesis and beyond: Mediating acquisition through collaborative dialogue. In J. P. Lantolf (Ed.), Sociocultural theory and second language learning (pp. 97-114). Oxford, England: Oxford University Press. 
Tahira, M. (2012). Behind MEXT's new course of study guidelines. The Language Teacher, 36(3), 3-8. Retrieved from http://jalt-publications.org/tlt/archive

Thomas, D. R. (2006). A general inductive approach for analyzing qualitative evaluation data. American Journal of Evaluation, 27, 237-246. https://doi.org/10.1177/1098214005283748

Thompson, P. (2008). Learning through extended talk. Language and Education, 22, 241-256. https://doi.org/10.2167/le754.0

Ushioda, E. (2013). Foreign language motivation research in Japan: An 'insider' perspective from outside Japan. In M. T. Apple, D. DaSilva, \& T. Fellner (Eds.), Language learning motivation in Japan (pp. 1-14). Bristol, England: Multilingual Matters.

Ushioda, E., \& Dörnyei, Z. (2009). Motivation, language identities and the L2 self: A theoretical overview. In Z. Dörnyei \& E. Ushioda (Eds.), Motivation, language identity and the L2 self (pp. 9-42). Bristol, England: Multilingual Matters.

Walsh, S. (2011). Exploring classroom discourse: Language in action. New York, NY: Routledge.

Yashima, T. (2002) Willingness to communicate in a second language: The Japanese context. The Modern Language Journal, 86, 54-66.

https://doi.org/10.1111/1540-4781.00136

Yashima, T. (2013). Imagined L2 selves and motivation for intercultural communication. In M. T. Apple, D. DaSilva, \& T. Fellner (Eds.) Language learning motivation in Japan (pp. 35-53). Bristol, England: Multilingual Matters.

\section{Appendix}

\section{Surveys}

SSI, SSR

Spring 2013

\section{STUDENT SURVEY}

AS Agree Strongly A Agree D Disagree DS Disagree Strongly 強くそう思う そう思う そうは思わない 強くそう思わない

1. In general, I like English.

2. I liked my high school English classes.

3. I need English because it will be useful in my future.

4. I have confidence in my English skills.

$\circ 000$

$\circ \circ 00$

$\circ \quad 0 \quad 0 \quad 0$

0000 
5. I studied hard in high school to improve my English skills.

6. I will study hard in university to improve my English skills.

7. I read an English novel (not 教科書) in high school English class.

8. I read an English novel on my own when I was in high school.

9. I will read an English novel on my own this semester.

10. I wrote an English journal (日記) for high school English class.

11. I wrote an English journal on my own when I was in high school.

12. I will write an English journal on my own this semester.

13. I watched an English movie for high school English class.

14. I watched an English movie on my own when I was in HS.

15. I like to watch movies in English.

16. Sometimes, I speak with my Japanese friends in English.

17. Sometimes, I watch the news in English.

18. Sometimes, I study vocabulary books to learn new words.

19. I lived in an English speaking country for a year or longer.

SOI, SOR, SOW

Fall 2013

\section{RESEARCH SURVEY on ENGLISH}

AS A D DS

a. I think about myself as an English speaker.

b. I use English in some way almost every day of my life.

c. I think the way I studied English in HS was generally effective.

d. I am proud of the English ability I have.

e. Instead of studying English, I'd rather study something in English.

f. It's easy for me to use English while living in Japan.

g. What is the biggest difference between the way you studied English in high school and the way you've studied in this class?

h. What activity in high school most helped to improve your English?

j. How do you plan to use English in your future? 